\title{
Molecular Identification of Trissolcus japonicus, Parasitoid of the Brown Marmorated Stink Bug, by Species-Specific PCR
}

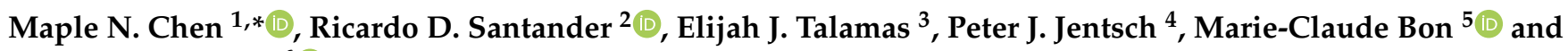 \\ Srđan G. Aćimović ${ }^{6}$ (i) \\ 1 Department of Biomedical Engineering, Cornell University, Ithaca, NY 14853, USA \\ 2 Hudson Valley Research Laboratory, School of Integrative Plant Sciences, \\ Plant Pathology and Plant-Microbe Biology Section, Cornell University, Highland, NY 12528, USA; \\ rd379@cornell.edu \\ 3 Department of Plant Industry, Florida Department of Agriculture and Consumer Services, Gainesville, \\ FL 32399, USA; elijah.talamas@fdacs.gov \\ 4 Hudson Valley Research Laboratory, Department of Entomology, Cornell University, Highland, NY 12528, \\ USA; pjj5@cornell.edu \\ 5 European Biological Control Laboratory, United States Department of Agriculture-ARS, \\ 34980 Montferrier-sur-Lez, France; mcbon@ars-ebcl.org \\ 6 Alson H. Smith Jr. Agricultural Research and Extension Center, Department of Plant Pathology, Physiology, \\ and Weed Science, Virginia Polytechnic Institute and State University, Winchester, VA 22602, USA; \\ acimovic@vt.edu \\ * Correspondence: mnc45@cornell.edu; Tel.: +1-(845)-505-2146
}

check for updates

Citation: Chen, M.N.; Santander, R.D.; Talamas, E.J.; Jentsch, P.J.; Bon, M.-C.; Aćimović, S.G. Molecular Identification of Trissolcus japonicus, Parasitoid of the Brown Marmorated Stink Bug, by Species-Specific PCR. Insects 2021, 12, 467.

https://doi.org/10.3390/

insects12050467

Academic Editor: Umberto Bernardo

Received: 31 March 2021

Accepted: 13 May 2021

Published: 18 May 2021

Publisher's Note: MDPI stays neutral with regard to jurisdictional claims in published maps and institutional affiliations.

Copyright: (c) 2021 by the authors. Licensee MDPI, Basel, Switzerland. This article is an open access article distributed under the terms and conditions of the Creative Commons Attribution (CC BY) license (https:// creativecommons.org/licenses/by/ $4.0 /)$.
Simple Summary: The brown marmorated stinkbug Halyomorpha halys, is an invasive pest that causes millions of dollars of crop damage each year in the US. A promising biocontrol agent for this pest is the samurai wasp, Trissolcus japonicus, which is a potential long term control method with few negative ecological impacts. However, the wasps' small size of only $1 \mathrm{~mm}$ in length can make it difficult to identify morphologically. We developed a DNA-based approach to determine whether a wasp specimen is T. japonicus using conventional methods of DNA extraction, PCR, and gel electrophoresis. When tested against eight families of Hymenoptera, including three Trissolcus species, our method identified samurai wasp samples with $100 \%$ accuracy. Additionally, in silico analyses of various T. japonicus sequences provide evidence that the method will work throughout the US, Europe, and parts of Asia. We expect that this method will be a valuable tool for reliably identifying T. japonicus during distribution and recapture efforts to assess its survival, establishment, and dispersal for biocontrol purposes.

Abstract: The samurai wasp, Trissolcus japonicus (Ashmead), has been proposed as a biocontrol agent against brown marmorated stink bugs (BMSB), due to its ability to parasitize and kill BMSB eggs. However, the wasps' small size makes it challenging for those untrained in morphological identification to determine the wasps' species. To circumvent this problem, a molecular method was created to identify T. japonicus. The method uses species-specific primers, designed in this study, which target the variable region of the mitochondrial Cytochrome Oxidase 1 (CO1) locus. After confirming successful DNA extraction from samples, the PCR amplification using our primers produced 227-bp PCR products for all T. japonicus specimens and no amplification in other microhymenoptera candidates. Additionally, DNA from BMSB-parasitized eggs gave positive PCR amplification, while the control BMSB samples showed no amplification. This indicates that PCR with our primers specifically and sensitively differentiates $T$. japonicus specimens from other similar wasp species and discriminates between T. japonicus-parasitized and non-parasitized BMSB eggs. Finally, an in silico analysis of $\mathrm{CO} 1$ sequences demonstrated that our primers match the sequences of four different haplotypes of T. japonicus, indicating that our diagnostic method could potentially be applied to analyze T. japonicus populations throughout North America, Europe, and parts of Asia.

Keywords: samurai wasp; PCR identification; species-specific primers; Halyomorpha halys; nondestructive DNA extraction 


\section{Introduction}

The brown marmorated stink bug (BMSB), Halyomorpha halys (Stål), is an invasive pentatomid pest that is native to China, Japan, and other parts of East Asia. Beginning in the late 20th century, the BMSB spread from East Asia to the US in 1996 [1], Canada in 2010 [2], Switzerland in 2007 [3], and Italy in 2012 [4]. Wherever it spreads, BMSB damage crops by feeding on fruit including pears, peppers, and tomatoes, causing fruit wounds and fruit abscission $[5,6]$. In fruit trees, BMSB can cause damage to over $25 \%$ of a tree's fruit. In 2010 alone, BMSB caused USD 37 million of crop damage in the mid-Atlantic US $[5,7]$. Looking towards the future, climate comparison models project that BMSB could spread throughout northern Europe, northeastern North America, southern Australia, New Zealand, and other locales between $30^{\circ}$ and $50^{\circ}$ in latitude [8].

A number of wasps have been observed to parasitize BMSB. Some are native to North America and Europe, including Anastatus sp., Ooencyrtus sp., Telenomus sp., and certain Trissolcus species. Of these, Anastatus has been shown to have the highest rates of parasitism in BMSB, especially Anastatus reduvii (Howard) in the US and Anastatus bifasciatus (Geoffrey) in Europe $[9,10]$. However, parasitoids native to North America typically show parasitism rates lower than $6 \%$ for $\mathrm{BMSB}$, and often have difficulty developing inside and emerging from BMSB eggs [11]. In contrast, parasitoids native to East Asia including Trissolcus japonicus (Ashmead) and strains of Trissolcus cultratus (Mayr) consistently show higher parasitism rates, typically above $50 \%$, and have greater rates of success for developing inside and emerging from BMSB eggs [9].

In particular, the samurai wasp T. japonicus has been considered as a promising biocontrol agent for BMSB in the US, since it can oviposit into and kill BMSB eggs at rates upwards of 70\% [12]. In its native habitat of East Asia, a combination of chemical and biological control methods, together with T. japonicus, have reduced BMSB to an occasional agricultural pest [13]. In the United States, T. japonicus was first discovered in the wild in 2014 in Beltsville, MD, and has been found in the mid-Hudson Valley of New York State since $2016[14,15]$. T. japonicus shows preference for BMSB eggs over those of other pentatomids such as the spined soldier bug Podisus maculiventris, minimizing its off-target ecological impacts [12,16-20]. Compared to established BMSB control methods such as insecticides and nets, T. japonicus has the potential to be less costly [21-28], more targetspecific, and it has demonstrated parasitism rates upwards of $80 \%$ [16]. T. japonicus's ability to kill BMSB at the egg stage prior to pest feeding makes it a promising candidate for BMSB control. Combined with established integrated pest management techniques, crop damage due to BMSB could be controlled to occasional outbreak levels as it is in East Asia [13].

One challenge that researchers have faced is reliably and rapidly identifying the wasps during field release and recapture endeavors. These endeavors are essential for measuring the survival and establishment of the wasps. Current methods rely heavily on expert morphological identification, which is time consuming. Species of Trissolcus, including T. japonicus, are only about $1 \mathrm{~mm}$ in length, making identification difficult and laborintensive for those without extensive training. Developing a simple method using standard molecular tools can provide reliable and fast results when identifying microhymenopteran candidates collected during survey. In this paper we designed, optimized, and validated a methodology for the PCR identification of T. japonicus individuals and T. japonicusparasitized BMSB eggs using novel species-specific primers targeting the variable region of the mitochondrial cytochrome c oxidase subunit 1 (CO1) locus. The high mutation rate of the $\mathrm{CO} 1$ locus allows it to be used to discriminate between closely related species and investigate intraspecific diversity and as such, is commonly used for genetic barcoding of species [29]. Species-specific primers were designed for use in monitoring survival of $T$. japonicus populations in the northeastern and mid-Atlantic United States. The method we present relies solely on species diagnostic PCR. Thus, we expect it to be a quick, accessible, and cost-efficient option to determine if a sample is T. japonicus, while still preserving a voucher specimen. 


\section{Materials and Methods}

\subsection{Primer Design}

Candidate primers for specific identification of T. japonicus were designed based on 19 different partial $\mathrm{CO} 1$ sequences at the $5^{\prime}$ end of the $\mathrm{CO} 1$ locus. Criteria for selection of species used were that the species was either closely related to T. japonicus [30] or could be mistaken for T. japonicus by untrained technicians, especially in the mid-Atlantic US [31]. The species included T. japonicus, closely related Palearctic species Trissolcus corai Talamas, Trissolcus kozlovi Rjakovskij, Trissolcus plautiae (Watanabe), T. cultratus, and Nearctic species of the flavipes group including Trissolcus euschisti (Ashmead) [30]. The list also included more distantly related taxa that may be visually mistaken for T. japonicus such as Telenomus podisi Ashmead, Platygastridae sp., Cerephronidae sp., and Encyrtidae sp. (Table 1) [31]. These sequences were acquired from the NCBI Nucleotide Database. Factors considered when selecting the sequences included location, sequence completeness, and sequence length, and because this study was conducted on samples from the mid-Atlantic United States, CO1 sequences from parasitoid wasps collected in North America were given preference whenever possible.

Table 1. CO1 sequences from NCBI belonging to 15 different Hymenoptera species used for speciesspecific primer design.

\begin{tabular}{lcc}
\hline Specimen ID & Family & Accession \# \\
\hline Trissolcus japonicus voucher TJ272 & Scelionidae & MK188350 \\
Trissolcus japonicus voucher TJ262 & Scelionidae & MK188360 \\
Trissolcus japonicus voucher Scel-0945 & Scelionidae & MK188349 \\
Trissolcus euschisti voucher Scel-0548 & Scelionidae & MK188347 \\
Trissolcus euschisti voucher FEMS015-09 & Scelionidae & MG939533 \\
Telenomus podisi isolate OH23 & Scelionidae & KR870966 \\
Trissolcus plautiae isolate: 121219-21 & Scelionidae & AB847133 \\
Trissolcus basalis voucher TSP228 & Scelionidae & MK188338 \\
Trissolcus kozlovi isolate T4 & Scelionidae & MH521283 \\
Trissolcus corai voucher USNM:ENT:01223976 & Scelionidae & MN615613 \\
Trissolcus cultratus voucher USNM:ENT:00977540 & Scelionidae & MN615602 \\
Telenomus podisi voucher BIOUG10919-B03 & Scelionidae & KR374962 \\
Telenomus sp. BIOUG24593-G02 & Scelionidae & MG498324 \\
Platygastridae sp. BOLD:AAZ4474 voucher & Platygastridae & KM556113 \\
BIOUG03482-G06 & Mymaridae & MH926817 \\
Mymaridae sp. INDOBIOSYS-CCDB25313-E11 & Ceraphronidae & MG442991 \\
Ceraphronidae sp. BIOUG32185-E11 & Pteromalidae & MN669960 \\
Pteromalidae sp. BOLD:ADS5523 voucher & Encyrtidae & MG447654 \\
CHARS00074-B06 & Cynipidae & MG442460 \\
Encyrtidae sp. BIOUG32169-A04 & & \\
Cynipidae sp. BIOUG23888-C07 & &
\end{tabular}

For primer design, $19 \mathrm{CO} 1$ sequences were first aligned using Codon Code Aligner (v.9.0.1) (https:/ / www.codoncode.com/aligner/) (accessed on 19 March 2021). Primers were designed manually, taking advantage of single nucleotide polymorphisms between the aligned sequences. Regions of divergence between the species were AT-rich, so longer primers were selected to achieve an acceptable annealing temperature. In particular, $3^{\prime}$ mismatches between strands of $\mathrm{G} / \mathrm{A}$ or $\mathrm{C} / \mathrm{C}$ were favored, as they are shown to have the greatest inhibition ability compared to $T / C, T / G, T / T, G / G$, and $C / A$ mismatches between strands [32-34].

To confirm that the candidate primers matched with target $T$. japonicus $C O 1$ sequences, 36 T. japonicus sequences from the US and Canada (MK188349, MW97094, MK188350, MW97071-MW97103) [35] were aligned with the primers using Unipro UGENE v38.1 [36]. Then, all available $T$. japonicus CO1 sequences were obtained and aligned to our primers, regardless of location. All sequences used in this analysis were obtained from NCBI GenBank. Finally, potential off-target amplifications from the primers were conducted 
using Primer-BLAST [37]. CO1 sequences from NCBI's non-redundant nucleotide (nr) database from Hymenoptera (taxid: 7399) or Hemiptera (taxid: 7524) organisms were screened for possible amplification, with a minimum of 4 total mismatches with at least 2 mismatches at the $3^{\prime}$ end of the primers.

\subsection{Sample Collection and Processing}

Hymenopteran parasitoids were collected on $10 \times 15 \mathrm{~cm}$ yellow sticky cards (Alpha Scents Inc., Canby, OR, USA) hung $1.5 \mathrm{~m}$ from the ground in trees and shrubs surrounding orchards throughout the mid-Hudson Valley and Finger Lakes region in New York. The cards were collected after 14 days, and a stereo microscope was used to identify wasp specimens. All samples collected in the field were morphologically identified to family, and sometimes to the genus and species level, ultimately representing eight families that could be mistaken visually for T. japonicus. Morphological identification was performed prior to removing the samples from the sticky cards and was done using taxonomic keys [38,39].

For the sample processing, small segments of the sticky cards containing parasitoids were carefully punched out from the yellow sticky card and debris was removed. The punch-out was submerged in synthetic mineral oil (Johnson \& Johnson, New Brunswick, NJ, USA) in a $30 \mathrm{~mL}$ plastic cup for $8 \mathrm{~h}$ or until the sample could be gently removed from the card with a clean paintbrush. Then the insect was dried off on a cleaning wipe, (Kimberly-Clark, Irvine, CA, USA) transferred into a microcentrifuge tube containing 95\% ethanol and incubated at room temperature for $2 \mathrm{~h}$. Finally, the sample was rinsed with sterile distilled water before proceeding to the non-destructive DNA extraction. To avoid cross-contamination, the paintbrush used to collect and manipulate the insect specimens was dipped in a $10 \%$ bleach solution, then $70 \%$ ethanol, followed by distilled water between handling samples [40].

\subsection{T. japonicus and BMSB Rearing Conditions}

Some of the analyzed specimens came from colonies of T. japonicus and H. halys reared at the Hudson Valley Research Laboratory in Highland, NY. Laboratory-reared adult $T$. japonicus which were originally collected in Milton, NY, were maintained at $25{ }^{\circ} \mathrm{C}$ at $50 \%$ relative humidity and a 16:8 h light-dark cycle in a growth chamber and were fed diluted raw honey. Stink bug colonies, originally caught in Highland, NY, were maintained in rearing tents under similar conditions, and were fed organic green beans, carrots, sunflower seeds, habanero peppers, and jalapeno peppers. A pepper plant placed in the rearing tent was used for BMSB oviposition [41].

Laboratory-reared T. japonicus and H. halys samples were collected and placed at $-20{ }^{\circ} \mathrm{C}$ to kill and store the specimens until use. Before DNA extraction, the specimens were thawed at room temperature.

\subsection{Genomic DNA Extractions}

Conventional genomic DNA extraction techniques involve destruction of the tissue sample, but for insect samples, it is desirable to retain an intact voucher for insect needle mounting and visual inspection. The insect voucher can be used to identify any samples for which PCR amplification was unsuccessful or to conduct morphological examination. For genomic DNA extraction, the DNeasy Blood and Tissue Kit (Qiagen, Hilden, Germany) was used, with modifications to make the process non-destructive to the insect voucher [42,43]. The intact sample was incubated in $180 \mu \mathrm{L}$ Buffer ATL and $20 \mu \mathrm{L}$ of $20 \mathrm{mg} \mathrm{mL}^{-1}$ proteinase $\mathrm{K}$ for $24-72 \mathrm{~h}$ at $55^{\circ} \mathrm{C}$, then the insect was removed and transferred to $70 \%$ ethanol for preservation. After adding Buffer AL to the lysate, the solution was incubated at $70{ }^{\circ} \mathrm{C}$ for $10 \mathrm{~min}$, and the manufacturer's protocol was followed. During elution, $50 \mu \mathrm{L}$ of Buffer $\mathrm{AE}$ warmed to $55^{\circ} \mathrm{C}$ was allowed to sit on the spin column membrane for $15 \mathrm{~min}$ before centrifugation to elute the DNA.

Amplifiability of the DNA extracted was assessed by PCR using universal primers for metazoan invertebrates LCO1490 (5'-GGT CAA CAA ATC ATA AAG ATA TTG G-3') 
and HCO2198 (5'-TAA ACT TCA GGG TGA CCA AAA AAT CA-3') [44]. This step serves to reduce the number of false negatives by identifying samples which had undergone inefficient DNA extraction or improper storage.

\subsection{Polymerase Chain Reaction Conditions}

Polymerase chain reaction (PCR) was performed in a $25 \mu \mathrm{L}$ reaction volume including 0.625 activity units of DreamTaq DNA Polymerase (Thermo-Fisher Scientific, Waltham, MA, USA), 1X Green DreamTaq Buffer, $0.2 \mathrm{mM}$ of each dNTP, $0.2 \mu \mathrm{M}$ of each primer, and $3 \mu \mathrm{L}$ template DNA per reaction. Conditions for thermal cycling included 4 min of initial denaturing at $95^{\circ} \mathrm{C}$, followed by 35 cycles consisting of $45 \mathrm{~s}$ of denaturing at $94{ }^{\circ} \mathrm{C}, 45 \mathrm{~s}$ of annealing at $58{ }^{\circ} \mathrm{C}$, and $1 \mathrm{~min}$ of elongation at $72{ }^{\circ} \mathrm{C}$, then a final elongation period of 5 min at $72{ }^{\circ} \mathrm{C}$ (Applied Biosystems 2720 GeneAmp Thermal Cycler, 96 wells, Thermo Fisher Scientific, Waltham, MA, USA). When verifying DNA extraction using the universal $\mathrm{LCO} 1490 / \mathrm{HCO} 2198$ primers, an annealing temperature of $40^{\circ} \mathrm{C}$ was used [43]. The optimal annealing temperature for the species-specific primers was determined experimentally using a gradient PCR ranging from 48 to $60{ }^{\circ} \mathrm{C}$ (Bio-Rad iCycler ${ }^{\mathrm{TM}}$ Thermal Cycler, 96 wells, Bio-Rad Laboratories, Hercules, CA, USA). Following PCR, $10 \mu \mathrm{L}$ of the PCR product were run on a $1.5 \%$ agarose gel stained with 1 X SYBR ${ }^{\mathrm{TM}}$ Safe DNA Gel Stain (Invitrogen, Carlsbad, CA, USA) together with $1 \mu \mathrm{L}$ of $1 \mathrm{~Kb}$ Plus DNA Ladder (Invitrogen, Carlsbad, CA, USA), then visualized using a Gel Doc XR+ Imaging System (Bio-Rad Laboratories, Hercules, CA, USA).

\subsection{Primer Specificity}

An initial in silico analysis was conducted to assess the primers' specificity against other common Trissolcus wasps that parasitize BMSB $[30,45]$. In this assay, we only selected species that we were not able to collect on sticky cards (Table 2).

Table 2. Trissolcus wasps that parasitize BMSB and their GenBank accession numbers.

\begin{tabular}{lll}
\hline Species & $n$ & Accession \# \\
\hline Trissolcus basalis & 5 & MK188338 \\
& & AB926023-AB926024 \\
& & AF380004 \\
Trissolcus belenus & 8 & MN615643-MN615644 \\
& & MN603802-MN603806 \\
\hline Trissolcus cultratus & 8 & MK906050 \\
\hline \multirow{2}{*}{ Trissolcus edessae } & 2 & MN615596-MN615603 \\
\hline Trissolcus hullensis & & MK188340 \\
& 4 & MN615575 \\
& & MT804753-MT804755 \\
Trissolcus plautiae & & KC778491 \\
& 23 & MN615614-MN615623 \\
& & AB908183-AB908186 \\
& & AB847147 \\
Trissolcus mitsukurii & AB847138-AB847142 \\
\hline Trissolcus utehensis & AB847133-AB847135 \\
\hline
\end{tabular}

Primers were then tested on genomic DNA extracted from morphologically identified specimens of T. japonicus to confirm successful amplification of a 227-bp band and correct 
sequence of the amplicon. Three randomly selected T. japonicus PCR amplicons were sequenced to verify that the amplified band matched the expected sequence. Then, to assess the specificity of the primers, 31 wasp specimens including T. japonicus and other morphologically similar and phylogenetically close species were tested with the speciesspecific primers after confirmation of successful DNA extraction (Table 3). These insect samples were collected with sticky cards, identified using taxonomic keys for insects [38,39], and their DNA extracted as described above. Sample selection was limited to insects collected in New York State, USA, which had been stored on yellow sticky cards at room temperature for fewer than three years.

\subsection{Primer Sensitivity}

In order to test the sensitivity of the novel primers designed in this study, the speciesspecific PCR reactions were run using different amounts of T. japonicus DNA in a $25 \mu \mathrm{L}$ reaction: 50, 10, 5, 1, 0.5, 0.1, 0.05 and $0.01 \mathrm{ng}$. Due to the inability of NanoDrop spectrophotometer instruments to accurately report DNA concentrations lower than $5 \mathrm{ng} \mu \mathrm{L}^{-1}$, a concentrated DNA stock was extracted from pooling 30 T. japonicus wasps which was reliably detected using a NanoDrop 1000 UV/VIS spectrophotometer (Thermo Fisher Scientific, Waltham, MA, USA), then diluted to yield the appropriate DNA concentrations used in PCR.

\subsection{Application to Parasitized Eggs}

After T. japonicus emerges from parasitized BMSB eggs, the eggs are left largely empty. The ability to determine whether an empty egg has been parasitized by T. japonicus can be a valuable tool in determining the success of T. japonicus as a biological control agent, and molecular diagnostic assays have been successfully developed for other parasitoids [40,46].

To evaluate the ability of the primers to sensitively detect $T$. japonicus DNA in parasitized BMSB eggs, the primers were tested on eight samples consisting of empty (emerged) BMSB eggs previously parasitized by $T$. japonicus. To confirm the wasp species parasitizing the eggs, we collected samples from laboratory-reared T. japonicus colonies. After emergence of T. japonicus from BMSB eggs, eggs and wasps were placed at $-20{ }^{\circ} \mathrm{C}$ for one week to kill the wasps. Then, the eggs were stored in a petri dish at room temperature until use. At the time of DNA extraction, eggs had been stored for two years under these conditions. Because of the lack of non-parasitized BMSB eggs when the assay was performed, we used three BMSB samples from lab-reared colonies to control for false positive PCR amplification of BMSB DNA.

In this assay, destructive DNA extraction using the DNeasy Blood and Tissue Kit (Qiagen, Hilden, Germany) was performed and confirmed using universal primers LCO1490/HCO2198, then the extracted DNA was amplified using the species-specific primers and run on an agarose gel.

\section{Results}

\subsection{Species-Specific Primer Design and Optimization of PCR Conditions}

Species-specific primer design was conducted using three T. japonicus CO1 sequences from specimens collected in North America (MK188350, MK188360, MK188349), as well as CO1 sequences of microhymenopteran species listed in Table 1. Two unique primers for $T$. japonicus were designed, TJ234F (5'-ATC CCA TCA TTA ATT TTA TTA ATC TAT AGG-3') and TJ460R (5'-CAT GTA AAT AAC GTT CAA TTA TTA ATT GAT A-3'), which produced a theoretical 227-bp PCR amplicon (Supplementary Figure S1). When primers were tested in vitro using T. japonicus DNA as template, a PCR product of $227 \mathrm{bp}$ was obtained. Sequencing and BLAST analyses of three randomly selected PCR products confirmed that the amplified DNA matched the T. japonicus CO1 gene. No non-target amplification of T. japonicus DNA was observed at any of the annealing temperatures assayed, ranging between $48^{\circ} \mathrm{C}$ and $60^{\circ} \mathrm{C}$. To reduce chances for non-specific amplification 
when analyzing DNA of other wasp species, we selected the highest annealing temperature of $58{ }^{\circ} \mathrm{C}$ that produced strong amplification of the target DNA.

For the primer design, T. japonicus CO1 sequences from US and Canadian specimens were aligned to sequences of other parasitoid wasps. The total number of primer mismatches between T. japonicus and the CO1 sequences of the remaining wasp species ranged from five (T. kozlovi, MH521283; T. euschisti, MG939533) to 30 (Encyrtidae sp., MG447654). In most cases, mismatches accumulated in the $3^{\prime}$ regions of both primers (Figure 1 ). The Primer-BLAST [37] specificity analysis using the North American T. japonicus CO1 sequences as templates and primers TJ234F/TJ460R confirmed a variable number of primer mismatches $(\geq 4)$, including at least two mismatches at the $3^{\prime}$ end of both primers with relevant non-T. japonicus species.

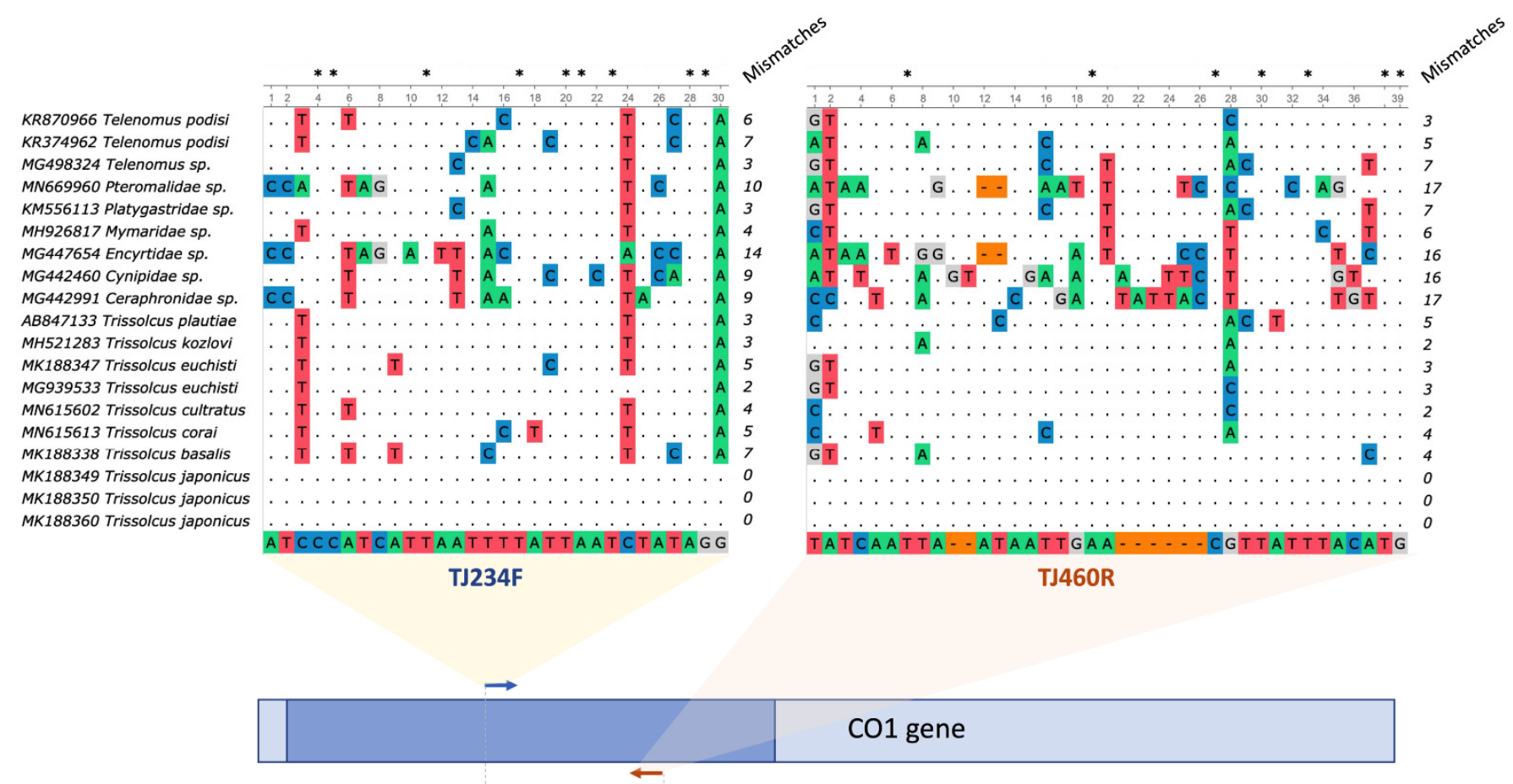

$227 \mathrm{bp}$

Figure 1. Alignment of TJ234F and TJ460R primers to various Hymenoptera CO1 sequences, and location of primers within CO1 locus. Detail of the CO1 sequence alignment at the TJ234F/TJ460R primer binding sites of T. japonicus specimens used for primer design and other wasp species related to or coexisting in the same habitat as T. japonicus. Identical nucleotides in primers and the target sequences are marked with dots. Colored letters and dashes highlight nucleotide dissimilarities between primers and target sequences. The number of nucleotide mismatches is summarized in the column at the right side of each alignment. Asterisks above the alignments show the position of conserved nucleotides within primer sequences. The cartoon at the bottom of the figure represents an approximate location at the $5^{\prime}$ end of the analyzed partial CO1 sequences (dark blue rectangle) and primer binding sites (arrows) within the complete CO1 gene sequence (pale blue rectangle), as well as the theoretical amplicon size.

\subsection{Primer Specificity}

The specificity of the TJ234F/TJ460R primer pair was tested in vitro with nine specimens of T. japonicus from three different locations within New York State, along with 22 other wasp specimens collected from locations where T. japonicus is present (Table 3). The samples consisted of parasitoids of BMSB including T. euschisti, T. brochymenae, and Telenomus podisi, which exhibit low rates of BMSB parasitism [16,30], as well as those that do not parasitize BMSB including samples of Amitus Haldeman (Platygastridae) and speci- 
mens in the families Pteromalidae, Myrmaridae, Encyrtidae, Eulophidae, Ceraphronidae, and Cynipidae [47-53]. Success of the non-destructive DNA extraction method used was confirmed, resulting in $81 \%$ of insect samples being accepted after PCR with the LCO1490/HCO2198 universal primers [44]. Using our species-specific primers, 100\% of $T$. japonicus samples produced recognizable bands after PCR $(n=9)$, while none of the other 12 wasp species did $(n=22)$ (Table 3$)$.

Table 3. Insect specimens evaluated by PCR in this study. The identification and origin of all insect samples for in vitro assays along with their collection year and PCR results.

\begin{tabular}{|c|c|c|c|c|c|}
\hline$n^{\mathrm{a}}$ & $\begin{array}{l}\text { Sample Type and Specimen } \\
\text { Identification } b\end{array}$ & Location & $\begin{array}{l}\text { Collection } \\
\text { Year }\end{array}$ & Control PCR $^{c}$ & Tj Specific PCR ${ }^{d}$ \\
\hline \multirow[t]{30}{*}{29} & Field-collected insects & & & & \\
\hline & Trissolcus japonicus & Poughkeepsie, NY & 2019 & + & + \\
\hline & Trissolcus japonicus & Poughkeepsie, NY & 2019 & + & + \\
\hline & Trissolcus japonicus & Campbell Hall, NY & 2018 & + & + \\
\hline & Trissolcus japonicus & Campbell Hall, NY & 2018 & + & + \\
\hline & Trissolcus japonicus & Campbell Hall, NY & 2018 & + & + \\
\hline & Trissolcus japonicus & Campbell Hall, NY & 2018 & + & + \\
\hline & Trissolcus japonicus & Campbell Hall, NY & 2018 & + & + \\
\hline & Trissolcus euschisti & Monroe County, NY & 2018 & + & - \\
\hline & Trissolcus euschisti & Highland, NY & 2020 & + & - \\
\hline & Trissolcus brochymenae & Huron, NY & 2018 & + & - \\
\hline & Trissolcus brochymenae & Poughkeepsie, NY & 2019 & + & - \\
\hline & Telenomus podisi & New Paltz, NY & 2018 & + & - \\
\hline & Telenomus podisi & Milton, NY & 2019 & + & - \\
\hline & Telenomus sp. & Campbell Hall, NY & 2020 & + & - \\
\hline & Telenomus sp. & Poughkeepsie, NY & 2018 & + & - \\
\hline & Amitus sp. & New Paltz, NY & 2019 & + & - \\
\hline & Amitus sp. & Monroe County, NY & 2019 & + & - \\
\hline & Pteromalidae sp. & Marlboro, NY & 2019 & + & - \\
\hline & Pteromalidae sp. & Warwick, NY & 2020 & + & - \\
\hline & Pteromalidae sp. or Myrmaridae sp. ${ }^{e}$ & Walden, NY & 2019 & + & - \\
\hline & Encyrtidae sp. & Monroe County, NY & 2019 & + & - \\
\hline & Encyrtidae sp. & Campbell Hall, NY & 2018 & + & - \\
\hline & Eulophidae sp. & Monroe County, NY & 2019 & + & - \\
\hline & Eulophidae sp. & Monroe County, NY & 2019 & + & - \\
\hline & Eulophidae sp. & Huron, NY & 2018 & + & - \\
\hline & Ceraphronidae sp. & New Paltz, NY & 2018 & + & - \\
\hline & Ceraphronidae sp. & Holley, NY & 2018 & + & - \\
\hline & Cynipidae sp. & New Paltz, NY & 2019 & + & - \\
\hline & Cynipidae sp. & Williamson, NY & 2019 & + & - \\
\hline \multirow[t]{2}{*}{13} & Laboratory-reared specimens & & & & \\
\hline & Trissolcus japonicus & HVRL & 2020 & + & + \\
\hline 2 & Trissolcus japonicus & HVRL & 2020 & + & + \\
\hline 8 & Halyomorpha halys parasitized eggs ${ }^{\mathrm{f}}$ & HVRL & 2020 & + & + \\
\hline 3 & Halyomorpha halys $\mathrm{g}$ & HVRL & 2020 & - & - \\
\hline
\end{tabular}

${ }^{\mathrm{a}} n$, Number of analyzed samples. ${ }^{\mathrm{b}}$ Field samples were collected using yellow sticky cards and identified based on morphology and other characters [38,39]. Laboratory-reared insects came from colonies maintained in the rearing facility at the Hudson Valley Research Laboratory (HVRL) in Highland, NY. ${ }^{\mathrm{c}}$ DNA extraction control PCR using the universal primers LCO1490/HCO2198 [44]. This assay was used to discard potential false negative reactions due to poor DNA extractions. ${ }^{\mathrm{d}} \mathrm{Tj}, \mathrm{T}$. japonicus specific PCR designed in this study, using primers TJ234F/TJ460R. ${ }^{\text {e }}$ Ambiguous specimen taxonomic identification based on morphological characters. ${ }^{\mathrm{f}}$ For the analysis we used parasitized and emerged H. halys eggs. DNA was extracted individually from 8 eggs. ${ }^{\mathrm{g}}$ DNA was extracted from legs of 3 adult specimens.

An in silico assay analyzed potential off-target annealing between our primers TJ234F/ TJ460R and eight species of Trissolcus that parasitize BMSB, excluding T. japonicus. Alignment of all publicly available sequences for these species to our primers revealed that all eight species had mismatches to the species-specific primers (Figure 2). Numbers of mismatches between the Trissolcus sequences and the two primers ranged from seven ( $T$. cultratus) to 32 (T. basalis), and all species showed a $3^{\prime}$ mismatch to the forward primer. All species except for T. mitsukurii showed $3^{\prime}$ mismatches to the reverse primer as well. Across the eight species analyzed, T. basalis, T. belenus, T. cultratus, T. hullensis, T. mitsukurii, and T. utahensis had two or more patterns of mismatch in the primer binding region, and each pattern is shown in Figure 2. 


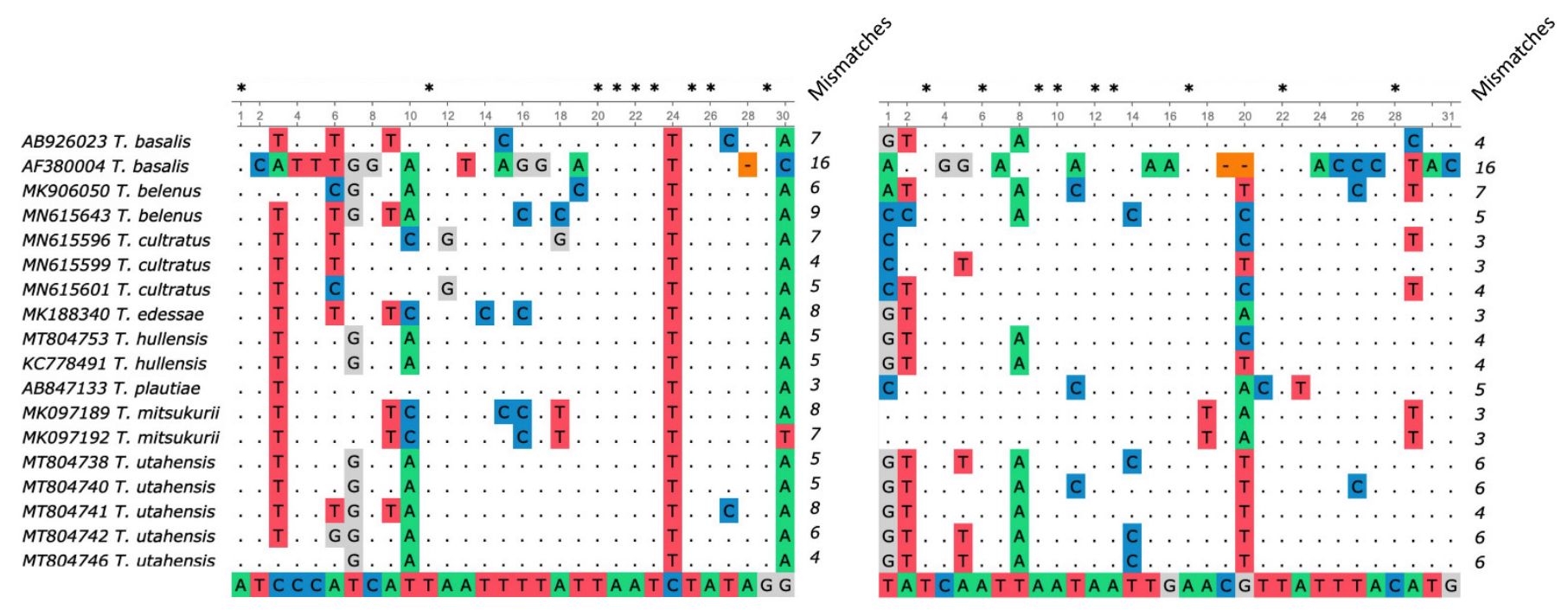

Figure 2. Alignment of TJ234F/TJ460R primers with sequences of eight BMSB parasitoids other than T. japonicus. Mismatch patterns of T. basalis, T. belenus, T. cultratus, T. edessae, T. hullensis, T. plautiae, T. mitsukurii and T. utehensis to our primers are shown. For each of the wasp species included in the figure, we analyzed a variety of sequences and identified diverse haplotypes. Frequently, two or more haplotypes showed the same pattern of mismatches across our two primer binding sites. Accordingly, a mismatch pattern in the figure may be found in one or more CO1 haplotypes of the corresponding species. Dots denote identical nucleotides in primers and the target sequences. Colored letters or dashes indicate nucleotide dissimilarities, and the total number of mismatches for each species' mismatch pattern is listed in columns to the right of the alignment. Asterisks indicate the position of conserved nucleotides within primer sequences. TJ234F/TJ460R are shown.

To test the applicability of our primers to larger populations of T. japonicus, a total of 103 CO1 sequences were analyzed, representing populations from Europe $(n=11)$, North America $(n=36)$, and Asia $(n=56)$ (Table 4) [54,55]. Since the primers were intended for use in North America, these samples were analyzed first. Across the 36 T. japonicus CO1 sequences collected from British Columbia (Canada) and 11 different states in the US, only one haplotype was observed, indicating that there is no apparent genetic variation in the barcoding region of the CO1 locus within the United States and Canadian populations of $T$. japonicus [35]. The recorded partial CO1 sequence of all North American samurai wasps matched the haplotype $\mathrm{H} 2$ reported by Stahl et al. [56], which was derived from a specimen collected in China (MH919759). This indicates that there is no evidence to suggest that the primers will not amplify T. japonicus DNA collected anywhere in the US.

After aligning additional CO1 gene sequences from Europe and Asia to our primers, we found that the species-specific primers matched with $100 \%$ of the CO1 sequences from Switzerland and Italy (11 sequences), $66.7 \%$ of the sequences from China (10 out of 15), $50 \%$ of the sequences from South Korea (1 out of 2 ) and $41 \%$ of those from Japan (16 out of 39). This represents a $71 \%$ of all T. japonicus sequences in NCBI GenBank.

Additional analysis based on the haplotype classification performed by Stahl et al. [56] revealed that primers are especially suited for the identification of T. japonicus haplotypes H1-H4 (Supplementary Figure S2), which include all the specimens from the US, Canada, Switzerland and Italy, plus variable percentages of specimens from China, South Korea and Japan (Table 4). The remaining haplotypes H5-H6, which have been reported only in Japan, showed a $3^{\prime}$ mismatch with the forward primer TJ234F, which could result in high false negative rates (Supplementary Figure S2) [56]. Finally, six haplotypes not previously described were categorized as haplotypes H7-H12. The six new haplotypes have only been reported in East Asia, and five of the six new haplotypes, H6 and H8-H12, showed at least one mismatch with our species-specific primers at the $3^{\prime}$ end, indicating that our primers are not well suited for identifying them (Table 4; Supplementary Figure S2). H7 showed only one mismatch to our primers, $6 \mathrm{bp}$ from the $3^{\prime}$ end of the reverse primer TJ460R. In order to confirm the geographic locations of the haplotypes H1-H4 for which 
the species-specific primers will reliably amplify, all publicly available T. japonicus CO1 sequences were categorized into twelve haplotypes, with their geographic origins noted (Table 4). The nucleotide markers used to distinguish between haplotypes at the CO1 locus, including the six new haplotypes H7-H12 are shown in Supplementary Figure S4, and a barcode haplotype network linking haplotypes and geographic origins created with PopART [57] are provided as Supplementary Material (Supplementary Figures S3 and S4). Categorization of T. japonicus sequences confirmed that our species-specific primers TJ234F/TJ460R will reliably amplify samurai wasp specimens originating from North America and Europe, which are so far entirely composed of haplotypes H1-H4.

Table 4. Geographic origin and CO1 haplotypes of T. japonicus analyzed in this study. Sequences of T. japonicus are grouped based on geographic origin down to the country or state, and haplotype(s) including those described by Stahl et al. (2019) [55].

\begin{tabular}{|c|c|c|c|c|c|c|c|}
\hline Geographic Origin & Haplotype a & $\begin{array}{l}\text { Representative } \\
\text { Sequences }\end{array}$ & $n^{\mathrm{c}}$ & $\begin{array}{c}\text { Geographic } \\
\text { Origin }\end{array}$ & Haplotype ${ }^{\text {a }}$ & $\begin{array}{l}\text { Representative } \\
\text { Sequences }^{b}\end{array}$ & $n^{\mathrm{c}}$ \\
\hline Europe & \multirow{3}{*}{$\mathrm{H} 11^{*}, \underset{*}{\mathrm{H} 1}{ }^{*}, \mathrm{H} 4$} & & 11 & Asia & & & 56 \\
\hline Switzerland & & MH919753-МH919758 & & China & & & \\
\hline Italy & & MK097184-MK097188 & & & $\mathrm{H} 2$ & MH919759 & \\
\hline North America & & & 36 & & $\mathrm{H} 2$ * & MK188348 & \\
\hline \multirow[t]{2}{*}{ Canada } & $\mathrm{H} 2$ * & MK188349 & & & & MK188354-MK188355 & \\
\hline & & MW97094 & & & & MK188358-MK188359 & \\
\hline US & $\mathrm{H} 2 *$ & & & & & MK188361-MK188362 & \\
\hline California & & MW97096 & & & & MN615624-MN615625 & \\
\hline District of Columbia & & MW97073 & & & $\mathrm{H} 7$ * & MK188357 & \\
\hline Delaware & & MW97079 & & & $\mathrm{H} 11^{\#}$ & MK188363 & \\
\hline \multirow[t]{4}{*}{ Maryland } & & MW97074 & & & & MN615630 & \\
\hline & & MW97076 & & & $\mathrm{H} 12^{\#}$ & MK188353 & \\
\hline & & MW97078 & & & & MN615632 & \\
\hline & & MW97093 & & Japan & & & \\
\hline \multirow{3}{*}{ New Jersey } & & MW97085-MW97086 & & & H1 & MH919743 & \\
\hline & & MW97089 & & & $\mathrm{H} 1{ }^{*}, \mathrm{H} 3 *, \mathrm{H}_{4} *$ & MK188351 & \\
\hline & & MW97091 & & & & MK188356 & \\
\hline \multirow[t]{3}{*}{ New York } & & MW97082 & & & & MN615628 & \\
\hline & & MK188350 & & & H3 & MH919744-MH919752 & \\
\hline & & MW97084 & & & $\mathrm{H} 4$ & AB847131-AB847132 & \\
\hline \multirow[t]{2}{*}{ Ohio } & & MW97097-MW97101 & & & & AB847136 & \\
\hline & & MW97103 & & & H5 & АВ908179-AB908182 & \\
\hline \multirow[t]{3}{*}{ Oregon } & & MW97077 & & & & AB847144-AB847145 & \\
\hline & & MW97087 & & & & AB894834-AB894835 & \\
\hline & & MK188360 & & & & AB894838-AB894839 & \\
\hline Pennsylvania & & MW97092 & & & $\mathrm{H} 5$ * & MN615626 & \\
\hline Utah & & MW97102 & & & H6 & AB847129-AB847130 & \\
\hline \multirow[t]{2}{*}{ Virginia } & & MW97071-MW97072 & & & & AB847137 & \\
\hline & & MW97088 & & & & AB847143 & \\
\hline \multirow[t]{4}{*}{ Washington } & & MW97075 & & & & AB847146 & \\
\hline & & MW97083 & & & & AB894836-AB894837 & \\
\hline & & MW97090 & & & & AB894840-AB894841 & \\
\hline & & MW97095 & & & $\mathrm{H} 8^{\#}$ & MN615627 & \\
\hline \multirow[t]{5}{*}{ West Virginia } & & MW97080-MW97081 & & & $\mathrm{H} 9{ }^{\#}$ & MN615633 & \\
\hline & & & & & $\mathrm{H} 10^{\#}$ & MN615631 & \\
\hline & & & & South Korea & & & \\
\hline & & & & & $\mathrm{H} 2$ * & MK188352 & \\
\hline & & & & & $\mathrm{H} 7^{\#}$ & MN615629 & \\
\hline
\end{tabular}

${ }^{a}$ Haplotypes H1-H6 were assigned to the reference sequences used by Stahl et al. (2019) [55]. Due to difference in sequence lengths, alignments with other T. japonicus CO1 sequences involved shortening the compared sequences from 423 to 373 nucleotides. ${ }^{b}$ NCBI accession numbers. ${ }^{c}$ Number of sequences in the NCBI database from the indicated continent. * Denotes sequences that potentially match the haplotypes defined by Stahl et al. [55] Multiple haplotypes associated with a sequence (or group of sequences) indicates sequences potentially belonging to one of the indicated haplotypes. \# Denotes sequences with haplotypes different from those described by Stahl et al. [55] based on the alignment of 373 nucleotide sequences, which have been arbitrary named H7-H12.

\subsection{PCR Validation on Parasitized Eggs}

Eight samples of BMSB eggs that had been parasitized by T. japonicus were analyzed along with three samples of BMSB DNA isolated from adult specimens' legs. Out of the eight samples of parasitized and emerged BMSB eggs, all showed bands when amplified with the TJ234F/TJ460R primers, while none of the BMSB DNA samples showed positive amplification (Table 3). After destructive DNA extraction, no egg samples were rejected due to insufficient DNA, while one BMSB tissue sample was rejected. 


\subsection{Primer Sensitivity}

After challenging the novel primers with T. japonicus DNA in amounts of 50, 10, 5, 1, $0.5,0.1,0.05$ and $0.01 \mathrm{ng}$ in a $25 \mu \mathrm{L}$ PCR reaction, the primers produced the expected 227-bp band in samples receiving $0.1 \mathrm{ng}$ or more of template DNA in a $25 \mu \mathrm{L}$ reaction (Figure 3). Bright, recognizable bands were produced in samples containing greater than $0.5 \mathrm{ng}$ of DNA in a $25 \mu \mathrm{L}$ reaction volume, and the sample containing $0.1 \mathrm{ng}$ of DNA showed a positive, faint band (Figure 3). Samples receiving $0.05 \mathrm{ng}$ or less of template DNA in a $25 \mu \mathrm{L}$ reaction did not produce bands bright enough to be reliably visualized under our current transillumination conditions.

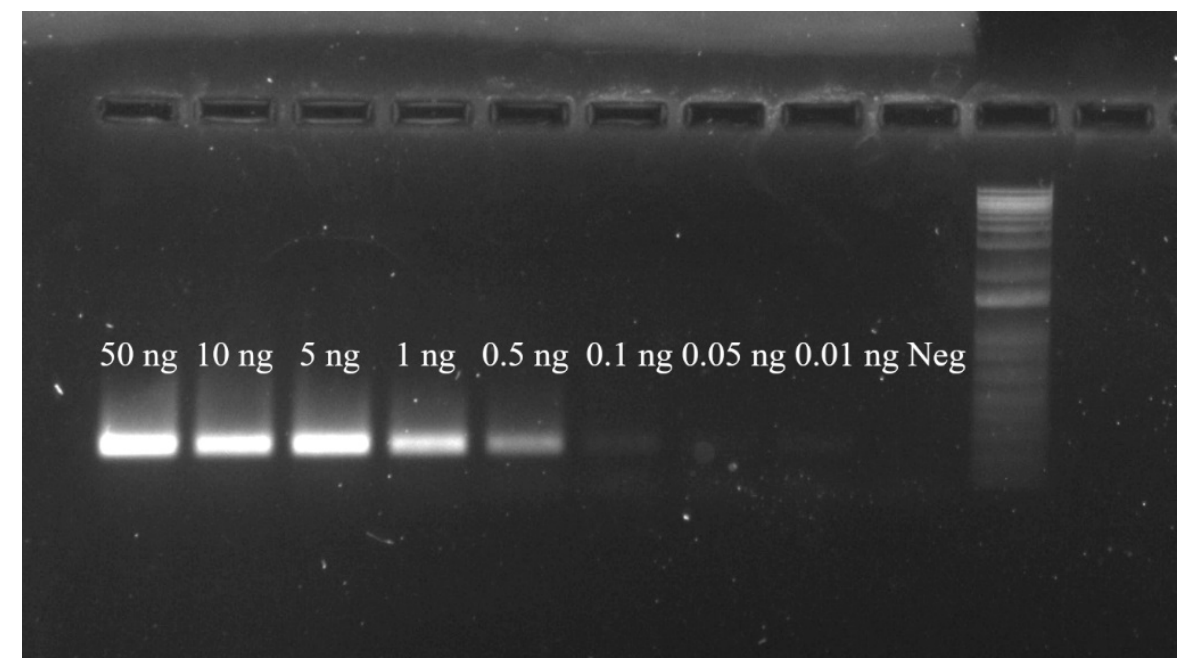

Figure 3. Sensitivity of the novel T. japonicus specific PCR using TJ234F and TJ460R primers. Total DNA amounts used in PCR were 50, 10, 5, 1, 0.5, 0.1, 0.05 and $0.01 \mathrm{ng}$, and a negative control (Neg) with $0 \mathrm{ng}$ in a $25 \mu \mathrm{L}$ reaction. The rightmost well contains $1 \mu \mathrm{L}$ of $1 \mathrm{~Kb}$ Plus DNA Ladder (Invitrogen, Carlsbad, CA, USA).

\section{Discussion}

In vitro and in silico assays have demonstrated that our method reliably and sensitively detects $T$. japonicus DNA in both adult wasps and parasitized eggs. These results agreed with a previous Primer-BLAST (NCBI) analysis of the primers' specificity, indicating that this method can be used reliably to distinguish samples of T. japonicus from those of tested wasps. For wasp species not tested in this study, such as Trissolcus cosmopeplae, additional study should be done to confirm the primers' specificity. However, since this study analyzed the close relatives of T. japonicus, which have the most conserved CO1 regions, the risk of non-target amplification of more distantly related Trissolcus species is low. The PCR using our primers is sensitive, producing bands at DNA concentrations as low as $0.1 \mathrm{ng}$ in a $25 \mu \mathrm{L}$ reaction and showing success for samples as old as 2 years since collection, stored on their yellow sticky cards at room temperature. During the control PCR step, $19 \%$ of samples were rejected due to low or degraded DNA, but more efficient DNA extraction techniques might be used to decrease this number. In future applications, the pairing of our single-step PCR method and a reliable DNA extraction method could lessen the need for a control PCR to samples that do not amplify with the species-specific primers. This alternative protocol has the potential to save time and money.

A broader in silico analysis of the target T. japonicus haplotypes $\mathrm{H} 1-\mathrm{H} 4$ [55] indicated that the primers show $100 \%$ homology with the target regions of the CO1 locus for these haplotypes. These four haplotypes constitute $71 \%$ of the $T$. japonicus sequences in the NCBI database, including all the North American, Swiss, and Italian sequenced specimens, and $48 \%$ of the Asian sequenced specimens. In other haplotypes, including the six new haplotypes identified by examining publicly available $C O 1$ sequences, the primers showed at least one mismatch, including a $3^{\prime}$ mismatch with the forward primer TJ234F in seven 
out of eight remaining haplotypes $(\mathrm{H} 6, \mathrm{H} 8-\mathrm{H} 12)$, that could result in false negative results. Haplotype $\mathrm{H} 7$ only showed one mismatch in reverse primer $6 \mathrm{bp}$ from the $3^{\prime}$ end, suggesting that the TJ234F/TJ460R primers could potentially identify H7 haplotypes as well. However, further work will have to be done to validate the ability of our primers to anneal to H7 DNA. All eight haplotypes that display at least one mismatch (H5-H12) have only been reported in East Asia, indicating that the method will work in North America and Europe.

In tests on BMSB eggs parasitized by samurai wasps, $100 \%$ of parasitized eggs produced T. japonicus-specific diagnostic bands even in samples analyzed 2 years after the emergence of the wasps. Our species-specific primers produced no amplicons in control BMSB tissue samples. This expands the applicability of our PCR assay, as it can be used to determine if eggs were parasitized by T. japonicus without inspecting the emerged adults. For field studies, this could offer insight to the success of T. japonicus in parasitizing BMSB eggs.

Considering the agricultural importance of the samurai wasp, the ability to quickly identify T. japonicus specimens and T. japonicus-parasitized BMSB eggs is an important tool for present and future research. In the mid-Atlantic US, efforts are currently underway to redistribute the samurai wasp to mitigate crop damage from BMSB [31]. Surveying of redistributed T. japonicus is especially important to assess the ability of the adventive species to overwinter, the efficiency at which it parasitizes BMSB, the time frame in which parasitism tends to occur, and the identity of the parasitoid in the absence of the emerged insect itself $[16,58]$. In all these studies, a rapid identification method can facilitate the speed and accessibility of research.

Current methods require either morphological examination or PCR-amplification and sequencing of the variable CO1 region [40,59]. In contrast, a PCR assay such as the one we present does not require the extra steps, time, or costs of sending samples for sequencing, or require the extensive training to accurately identify samples morphologically $[60,61]$ The PCR designed in this study allows specific identification of T. japonicus using speciesspecific primers. Our method is faster than sequencing, which has a turnaround time of a few days, easy to interpret, and the materials required to perform a PCR are currently present in many laboratories. PCR and gel electrophoresis for molecular identification are established techniques for taxonomic identification of insect samples, but our method is unique because existing methods typically do not achieve species-level identification [40,46]. The ubiquity of PCR equipment allows many laboratories to conduct these analyses inhouse, with shorter turnaround times than either of the prior methods, expediating studies on T. japonicus as a biocontrol agent for BMSB.

In sum, our method is both an accessible and reliable way to identify T. japonicus, a promising biocontrol agent for BMSB in the US. With redistribution efforts underway, the established range of the samurai wasp will likely increase, and so will demands for identification for the study of the parasitoid's capacity to overwinter, parasitism rate, and potential effect on ecologically important pentatomids [15]. In this setting, the quick and inexpensive nature of our method will be a valuable tool for identification of the samurai wasp. Further work could aim to (i) create a multiplex PCR protocol combining both universal primers and primers specific for T. japonicus, dramatically reducing the workload of the method; (ii) optimize on our method for the T. japonicus haplotype and Hymenoptera biodiversity at different geographical locations; (iii) and/or develop multiplex or quantitative PCRs for simultaneous detection and identification of different $T$. japonicus $C O 1$ sequences or Trissolcus species.

Supplementary Materials: The following are available online at https:/ /www.mdpi.com/article/10 .3390/insects12050467/s1, Figure S1: Alignment of TJ234F/TJ460R primers against three T. japonicus sequences, Figure S2: Alignment between T. japonicus CO1 haplotypes and TJ234F/TJ460R primer mismatches, Figure S3: Barcode haplotype network of the T. japonicus CO1 sequences analyzed in this study, Figure S4: Position of haplotype markers in T. japonicus CO1 sequence.

Author Contributions: Conceptualization, P.J.J. and S.G.A.; methodology, M.N.C., R.D.S., and E.J.T.; validation, M.N.C. and R.D.S.; formal analysis, M.N.C. and R.D.S.; investigation, M.N.C., E.J.T., and 
M.-C.B.; resources, P.J.J. and S.G.A.; writing—original draft preparation, M.N.C.; writing-review and editing, M.N.C., R.D.S. and E.J.T.; visualization, M.N.C. and R.D.S.; supervision, P.J.J. and S.G.A.; project administration, P.J.J. and S.G.A.; funding acquisition, P.J.J. and S.G.A. All authors have read and agreed to the published version of the manuscript.

Funding: This work is supported with funding from the 2019-20 New York Apple Research and Development Program (ARDP) and Specialty Crop Research Initiative (USDA-NIFA SCRI \#201651181-25409), the Florida Department of Agriculture and Consumer Services, Division of Plant Industry, annual USDA-APHIS Farm Bill awards, and S.G.A.'s discretionary research program funds.

Institutional Review Board Statement: Not applicable.

Informed Consent Statement: Not applicable.

Data Availability Statement: All analyzed data is publicly available at NCBI Nucleotide Database: www.ncbi.nlm.nih.gov/genbank/ (accessed on 18 May 2021).

Acknowledgments: We would like to thank C. L. Meredith, F. Khodadadi, L. M. Brown, M. Stewart, and J. Jaeger for technical support. We are grateful for H. Firstencel, and A. Walker for their work in selecting T. japonicus candidates from yellow sticky cards. Finally, we would like to extend appreciation to T. Lampasona, D. Aćimović, and A. Hepworth for their help in procuring the original T. japonicus colony.

Conflicts of Interest: The authors declare no conflict of interest. The funders had no role in the design of the study; in the collection, analyses, or interpretation of data; in the writing of the manuscript, or in the decision to publish the results.

\section{References}

1. Hoebeke, E.R.; Carter, M.E. Halyomorpha halys (Stål) (Heteroptera: Pentatomidae): A polyphagous plant pest from Asia newly detected in North America. Proc. Entomol. Soc. Wash. 2005, 105, 225-237.

2. Fogain, R.; Graff, S. First records of the invasive pest, Halyomorpha halys (Hemiptera: Pentatomidae), in Ontario and Quebec. J. Entomol. Soc. Ont. 2011, 142, 45-48.

3. Wermelinger, B.; Wyniger, D.; Forster, B. First records of an invasive bug in Europe: Halyomorpha halys Stål (Heteroptera: Pentatomidae), a new pest on woody ornamentals and fruit trees? Alp. Entomol. 2008, 81, 1-8.

4. Maistrello, L.; Dioli, P.; Bariselli, M.; Mazzoli, G.L.; Giacalone-Forini, I. Citizen science and early detection of invasive species: Phenology of first occurrences of Halyomorpha halys in Southern Europe. Biol. Invasions 2016, 18, 3109-3116. [CrossRef]

5. Nielsen, A.L.; Hamilton, G.C. Seasonal occurrence and impact of Halyomorpha halys (Hemiptera: Pentatomidae) in tree fruit. J. Econ. Entomol. 2009, 102, 1133-1140. [CrossRef] [PubMed]

6. Bergmann, E.; Bernhard, K.M.; Bernon, G.; Bickterton, M.; Gill, S.; Gonzales, C.; Hamilton, G.C.; Hedstrom, C.; Kamminga, K.; Koplinka-Loehr, C.; et al. Host Plants of the Brown Marmorated Stink Bug in the U.S. Northeastern IPM Center. Available online: https:/ / www.stopbmsb.org/where-is-bmsb/host-plants / (accessed on 19 April 2021).

7. Leskey, T.C.; Nielsen, A.L. Impact of the invasive brown marmorated stink bug in north America and Europe: History, biology, ecology, and management. Annu. Rev. Entomol. 2018, 63, 599-618. [CrossRef]

8. Zhu, G.; Bu, W.; Gao, Y.; Liu, G. Potential geographic distribution of brown marmorated stink bug invasion (Halyomorpha halys). PLoS ONE 2012, 7, e31246. [CrossRef]

9. Haye, T.; Fischer, S.; Zhang, J.; Gariepy, T. Can native egg parasitoids adopt the invasive brown marmorated stink bug, Halyomorpha Halys (Heteroptera: Pentatomidae), in Europe? J. Pest. Sci. 2015, 88, 693-705. [CrossRef]

10. Jones, A.L.; Jennings, D.E.; Hooks, C.R.R.; Shrewsbury, P.M. Field surveys of egg mortality and indigenous egg parasitoids of the brown marmorated stink bug, Halyomorpha Halys, in ornamental nurseries in the Mid-Atlantic region of the USA. J. Pest. Sci. 2017, 90, 1159-1168. [CrossRef]

11. Dieckhoff, C.; Tatman, K.M.; Hoelmer, K.A. Natural biological control of Halyomorpha Halys by native egg parasitoids: A multi-year survey in Northern Delaware. J. Pest. Sci. 2017, 90, 1143-1158. [CrossRef]

12. Yang, Z.-Q.; Yao, Y.-X.; Qiu, L.-F.; Li, Z.-X. A new species of Trissolcus (Hymenoptera: Scelionidae) parasitizing eggs of Halyomorpha Halys (Heteroptera: Pentatomidae) in China with comments on its biology. Ann. Entomol. Soc. 2009, 102, 39-47. [CrossRef]

13. Lee, D.H.; Short, B.D.; Joseph, S.V.; Bergh, J.C.; Leskey, T.C. Review of the biology, ecology, and management of Halyomorpha Halys (Hemiptera: Pentatomidae) in China, Japan, and the Republic of Korea. Environ. Entomol. 2013, 42, 627-641. [CrossRef]

14. Talamas, E.J.; Herlihy, M.V.; Dieckhoff, C.; Hoelmer, K.A.; Buffington, M.; Bon, M.-C.; Weber, D.C. Trissolcus japonicus (Ashmead) (Hymenoptera, Scelionidae) emerges in North America. J. Hymenopt. Res. 2015, 43, 119-128. [CrossRef]

15. Jentsch, P. Expanding the range of the samurai wasp, Trissolcus japonicus, in New York orchards. N. Y. Fruit Q. 2017, $25,31-35$.

16. Herlihy, M.V.; Talamas, E.J.; Weber, D.C. Attack and success of native and exotic parasitoids on eggs of Halyomorpha halys in three Maryland habitats. PLoS ONE 2016, 11, e0150275. [CrossRef] [PubMed] 
17. Zhang, J.; Zhang, F.; Gariepy, T.; Mason, P.; Gillespie, D.; Talamas, E.; Haye, T. Seasonal parasitism and host specificity of Trissolcus japonicus in Northern China. J. Pest. Sci. 2017, 90, 1127-1141. [CrossRef] [PubMed]

18. Hedstrom, C.; Lowenstein, D.; Andrews, H.; Bai, B.; Wiman, N. Pentatomid host suitability and the discovery of introduced populations of Trissolcus japonicus in Oregon. J. Pest. Sci. 2017, 90, 1169-1179. [CrossRef]

19. Charles, J.G.; Avila, G.A.; Hoelmer, K.A.; Hunt, S.; Gardner-Gee, R.; MacDonald, F.; Davis, V. Experimental assessment of the biosafety of Trissolcus japonicus in New Zealand, prior to the anticipated arrival of the invasive pest Halyomorpha halys. BioControl 2019, 64, 367-379. [CrossRef]

20. Botch, P.S.; Delfosse, E.S. Host-acceptance behavior of Trissolcus japonicus (Hymenoptera: Scelionidae) Reared on the invasive Halyomorpha halys (Heteroptera: Pentatomidae) and nontarget species. Environ. Entomol. 2018, 47, 403-411. [CrossRef] [PubMed]

21. Jentsch, P.; Brown, L.; Canino, L.; Chen, M.; Jaeger, J.; Stewart, M.; Woelfersheim, A.; Kent, P. Results of 2020 Insecticide and Acaricide Studies in Eastern New York; Report for Hudson Valley Laboratory; Hudson Valley Laboratory: Highland, NY, USA, 2020.

22. Venerate ${ }^{\circledR}$ XC Bioinsecticide Improves Insect Control. Available online: https://marronebio.com/products/venerate/ (accessed on 22 March 2021).

23. Venerate ${ }^{\circledR}$ XC. Available online: http:/ /www.cdms.net/LabelsSDS/home/ (accessed on 29 March 2021).

24. Rutgers University New Jersey Agricultural Experiment Center. Pesticide Control for the Brown Marmorated Stink Bug. Available online: https: / / njaes.rutgers.edu/stink-bug/pesticides.php (accessed on 29 March 2021).

25. National Pesticide Information Center. Bifenthrin. Available online: http://npic.orst.edu/factsheets/bifgen.html (accessed on 22 March 2021).

26. National Pesticide Information Center. Cyfluthrin. Available online: http://www.npic.orst.edu/factsheets/cyfluthringen.html (accessed on 29 March 2021).

27. Drape Net Pty Ltd. Drape Net ${ }^{\circledR}$. Available online: https://drapenet.com/drape-net/\# (accessed on 22 March 2021).

28. Baker, B.P.; Green, T.A.; Loker, A.J. Biological control and integrated pest management in organic and conventional systems. Biol. Control 2020, 140, 104095. [CrossRef]

29. Mandal, S.D.; Chhakchhuak, L.; Gurusubramanian, G.; Kumar, N.S. Mitochondrial markers for identification and phylogenetic studies in insects-A review. DNA Barcodes 2014, 2, 1-9. [CrossRef]

30. Talamas, E.J.; Bon, M.-C.; Hoelmer, K.A.; Buffington, M.L. Molecular phylogeny of Trissolcus wasps (Hymenoptera, Scelionidae) associated with Halyomorpha halys (Hemiptera, Pentatomidae). J. Hymenopt. Res. 2019, 73, 201-217. [CrossRef]

31. Jentsch, P.; Agnello, A.; Tee, E.; Aćimović, D.; Brown, L. Biological Control of Brown Marmorated Stink Bug, Halyomorpha Halys Stål (Hemiptera: Pentatomidae) in NYS; Report for Hudson Valley Laboratory; Hudson Valley Laboratory: Highland, NY, USA, 2020.

32. Kwok, S.; Kellogg, D.E.; McKinney, N.; Spasic, D.; Goda, L.; Levenson, C.; Sninsky, J.J. Effects of primer-template mismatches on the polymerase chain reaction: Human immunodeficiency virus type 1 model studies. Nucleic Acids Res. 1990, 18, 999-1005. [CrossRef]

33. Simsek, M.; Adnan, H. Effect of single mismatches at $3^{\prime}$-End of primers on polymerase chain reaction. J. Sci. Res. Med. Sci. 2000, $2,11-14$.

34. Lefever, S.; Pattyn, F.; Hellemans, J.; Vandesompele, J. Single-nucleotide polymorphisms and other mismatches reduce performance of quantitative PCR assays. Clin. Chem. 2013, 59, 1470-1480. [CrossRef]

35. Bon, M.C. (United States Department of Agriculture-ARS, European Biological Control Laboratory, Montferrier-sur-Lez, France). Personal communication, March 2021.

36. Okonechnikov, K.; Golosova, O.; Fursov, M.; UGENE team. Unipro UGENE: A unified bioinformatics toolkit. Bioinformatics 2012, 28, 1166-1167. [CrossRef]

37. Ye, J.; Coulouris, G.; Zaretskaya, I.; Cutcutache, I.; Rozen, S.; Madden, T.L. Primer-BLAST: A tool to design target-specific primers for polymerase chain reaction. Bioinformatics 2012, 13, 134. [CrossRef]

38. Talamas, E.J.; Johnson, N.F.; Buffington, M. Key to nearctic species of Trissolcus Ashmead (Hymenoptera, Scelionidae), natural enemies of native and invasive stink bugs (Hemiptera, Pentatomidae). J. Hymenopt. Res. 2015, 43, 45-110. [CrossRef]

39. Borror, D.J.; Johnson, N.F.; Triplehorn, C.A. An Introduction to the Study of Insects; Saunders College Pub.: Philadelphia, PA, USA, 1989.

40. Stahl, J.M.; Gariepy, T.D.; Beukeboom, L.W.; Haye, T. A Molecular tool to identify anastatus parasitoids of the brown marmorated stink bug. Entomol. Exp. Appl. 2019, 167, 692-700. [CrossRef]

41. McIntosh, H.; Lowenstein, D.M.; Wiman, N.G.; Wong, J.S.; Lee, J.C. Parasitism of frozen Halyomorpha halys eggs by Trissolcus japonicus: Applications for rearing and experimentation. Biocontrol Sci. Technol. 2019, 29, 478-493. [CrossRef]

42. Taekul, C.; Valerio, A.A.; Austin, A.D.; Klompen, H.; Johnson, N.F. Molecular phylogeny of Telenomine egg parasitoids (Hymenoptera: Platygastridae s.1.: Telenominae): Evolution of host shifts and implications for classification. Syst. Entomol. 2014, 39, 24-35. [CrossRef]

43. Sabbatini-Peverieri, G.; Talamas, E.; Bon, M.-C.; Marianelli, L.; Bernardinelli, I.; Malossini, G.; Benvenuto, L.; Roversi, P.F.; Hoelmer, K. Two asian egg parasitoids of Halyomorpha Halys (Stål) (Hemiptera, Pentatomidae) emerge in Northern Italy: Trissolcus Mitsukurii (Ashmead) and Trissolcus japonicus (Ashmead) (Hymenoptera, Scelionidae). J. Hymenopt. Res 2018, 67, 37-53. [CrossRef]

44. Folmer, O.; Black, M.B.; Hoeh, W.; Lutz, R.; Vrijenhoek, R.C. DNA primers for amplification of mitochondrial cytochrome c oxidase subunit i from diverse metazoan invertebrates. Mol. Mar. Biol. Biotechnol. 1994, 3, 294-299. [PubMed]

45. Lara, J.; Pickett, C.; Ingels, C.; Haviland, D.R.; Grafton-Cardwell, E.; Doll, D.; Bethke, J.; Faber, B.; Dara, S.K.; Hoddle, M. Biological control program is being developed for brown marmorated stink bug. Calif. Agric. 2016, 70, 15-23. [CrossRef] 
46. Gariepy, T.D.; Haye, T.; Zhang, J. A molecular diagnostic tool for the preliminary assessment of host-parasitoid associations in biological control programmes for a new invasive pest. Mol. Ecol. 2014, 23, 3912-3924. [CrossRef]

47. Summy, K.R.; Gilstrap, F.E.; Hart, W.G.; Caballero, J.M.; Saenz, I. Biological control of citrus blackfly (Homoptera: Aleyrodidae) in Texas. Environ. Entomol. 1983, 12, 782-786. [CrossRef]

48. Machtinger, E.T.; Geden, C.J.; Leppla, N.C. Linear dispersal of the filth fly parasitoid Spalangia cameroni (Hymenoptera: Pteromalidae) and parasitism of hosts at increasing distances. PLOS ONE 2015, 10, e0129105. [CrossRef]

49. Huber, J.T.; Read, J.D.; Triapitsyn, S.V. Illustrated key to genera and catalogue of Mymaridae (Hymenoptera) in America North of Mexico. Zootaxa 2020, 4773, 1-411. [CrossRef]

50. Trjapitzin, V.A. A review of encyrtid wasps (Hymenoptera, Chalcidoidea, Encyrtidae) of macaronesia. Entomol. Rev. 2008, 88, 218-232. [CrossRef]

51. Kosheleva, O.V.; Kostjukov, V.V. Types of Parasitism in Eulophid Wasps (Hymenoptera, Eulophidae). Entmol. Rev. 2014, 94, 1202-1217. [CrossRef]

52. Krzyżyński, M.; Ulrich, W. Ceraphronidae and Megaspilidae (Hymenoptera: Ceraphronoidea) of Poland: Current state of knowledge with corrections to the Polish checklist. Pol. J. Entomol. 2015, 84, 191-200. [CrossRef]

53. Ronquist, F.; Nieves-Aldrey, J.-L.; Buffington, M.L.; Liu, Z.; Liljeblad, J.; Nylander, J.A.A. Phylogeny, evolution and classification of gall wasps: The plot thickens. PLoS ONE 2015, 10, e0123301. [CrossRef]

54. Matsuo, K.; Hirose, Y.; Johnson, N.F. A Taxonomic issue of two species of Trissolcus (Hymenoptera: Platygastridae) Parasitic on eggs of the brown-winged green bug, Plautia stali (Hemiptera: Pentatomidae): Resurrection of T. plautiae, a cryptic species of T. japonicus revealed by morphology, reproductive isolation and molecular evidence. Appl. Entomol. Zool. 2014, 49, 385-394.

55. Matsuo, K.; Honda, T.; Itoyama, K.; Toyama, M.; Hirose, Y. Discovery of three egg parasitoid species attacking the shield bug Glaucias subpunctatus (Hemiptera: Pentatomidae). Jpn. J. Appl. Entomol. Zool. 2016, 60, 43-45. [CrossRef]

56. Stahl, J.; Tortorici, F.; Pontini, M.; Bon, M.-C.; Hoelmer, K.; Marazzi, C.; Tavella, L.; Haye, T. First discovery of adventive populations of Trissolcus japonicus in Europe. J. Pest. Sci. 2019, 92, 371-379. [CrossRef]

57. Leigh, J.W.; Bryant, D. PopART: Full-feature software for haplotype network construction. Methods Ecol. Evol. 2015, 6, 1110-1116. [CrossRef]

58. Moraglio, S.T.; Tortorici, F.; Pansa, M.G.; Castelli, G.; Pontini, M.; Scovero, S.; Visentin, S.; Tavella, L. A 3-year survey on parasitism of Halyomorpha halys by egg parasitoids in Northern Italy. J. Pest. Sci. 2020, 93, 183-194. [CrossRef]

59. Gariepy, T.D.; Bruin, A.; Konopka, J.; Scott-Dupree, C.; Fraser, H.; Bon, M.-C.; Talamas, E. A modified DNA barcode approach to define trophic interactions between native and exotic pentatomids and their parasitoids. Mol. Ecol. 2019, 28, 456-470. [CrossRef]

60. Paparini, A.; Gofton, A.; Yang, R.; White, N.; Bunce, M.; Ryan, U.M. Comparison of sanger and next generation sequencing performance for genotyping cryptosporidium isolates at the 18S RRNA and actin loci. Exp. Parasitol. 2015, 151-152, 21-27. [CrossRef]

61. Schlatter, R.; Matte, U.; Polanczyk, C.; Koehler-Santos, P.; Ashton-Prolla, P. Costs of genetic testing: Supporting Brazilian public policies for the incorporating of molecular diagnostic technologies. Genet. Mol. 2015, 38, 332-337. [CrossRef] 